\title{
Chemical and Fertility Indicators of Soil Quality in Organic and Conventional Farming Systems in Egypt
}

\author{
Mai M. Ahmed", M. A. Daif, H.A. Khater* and M. Abdul \\ Aleem ${ }^{* * *}$ \\ *Soil Science Department, and ${ }^{* *}$ Soil Microbiology Department, \\ Faculty of Agriculture, Cairo University, Giza, Egypt.
}

\begin{abstract}
( RGANIC farming has gained ground worldwide and has expanded in recent years due to environmental, economic, and social concerns. In Egypt, up to $2.23 \%$ of the agricultural area is managed organically. The transition from conventional to organic farming is accompanied by changes in an array of soil properties and processes that affect soil fertility. These changes in soil properties under Egyptian condition are not well documented. Therefore, the present study was carried out to study the comparative effects of organic and conventional farming systems on some soil chemical indicators under Egyptian condition.
\end{abstract}

Surface soil samples $(0-30 \mathrm{~cm})$ were collected from eight field pairs (organic field and its conventional counterpart) to represent Organic farms in three locations (Fayoum (Tubhar village), Bilbeis city (SEKEM organic farm) and Salhyia City). The organic fields were in organic practice for 4, 6, and 10 years (Fayoum samples), 20 and 30 years (Sharkyia samples), 8, 10 and 12 years (Ismailia samples) since certification. The studied soil chemical indicators include soil organic carbon, T-N, pH, EC, CEC, exchangable cations, and available $\mathrm{N}, \mathrm{P}, \mathrm{K}, \mathrm{Fe}, \mathrm{Mn}, \mathrm{Zn}$ and $\mathrm{Cu}$.

Soil organic carbon, T-N, CEC, and available N, P, K, Fe, and Mn were significantly higher in the organic system than in the conventional system. Also, organically managed soils showed significantly better soil nutritional status regardless the periods of organic farming practice. On the other hand, soil $\mathrm{pH}, \mathrm{EC}$, available $\mathrm{Cu}$ and $\mathrm{Zn}$ were higher in the conventional system than in the organic system.

Keywords: Organic farming, Conventional, Soil quality indicators, Available nutrients.

Organic farming has gained ground worldwide and has expanded in the recent years due to environmental, economic and social concerns (Gasparatos et al., 2011). It has been proposed as an alternative agricultural system to solve the environmental problems arising from conventional farming management, such as pesticide application, excessive inputs of synthetic chemical fertilizers, soil 
degradation, and the presence of pesticide residues in food (Stockdale et al., 2001).

In Egypt, up to $2.23 \%$ of the agricultural area is managed organically according to European Union Regulation (Willer and Klicher, 2012).The transition from conventional to organic farming is accompanied by changes in an array of soil properties and processes that affect soil fertility (Clark et al., 1998 and Herencia et al., 2008). A growing number of studies showed that organic farming leads to higher quality soil and more soil biological activity than conventional farming. The impact of organic and conventional farming systems on soil showed that the organically managed soils contained higher levels of organic carbon (Mazoncini et al., 2010; Omar et al., 2010 and Wang et al., 2012), $\mathrm{pH}$, total nitrogen, CEC (Gadja and Martyniuk, 2005; Melero et al., 2006; Araujo et al., 2009), soluble phosphorus and potassium (Clark et al., 1998), and soil microbial growth and enzyme activities (Liu et al., 2007; Okur et al., 2009 and Wang et al., 2012). However, some authors reported some different trends (Marinari et al., 2006; Hathaway et al., 2011 and Gasparatos et al., 2011).

Soil quality depends on the physical, chemical, biological, and biochemical properties of the soil, changes in these properties must be taken into account in assessing changes in soil quality (Babu et al., 2010). The comparison of organic with conventional systems is complex and difficult (Watson et al., 2008). The objective of the present study was to compare the impacts of organic and conventional farming systems on some chemical and fertility indicators of soil under Egyptian conditions.

\section{Material and Methods}

Soil samples were collected from eight field pairs representing three locations in three governorates. In Fayoum governorate, three field pairs were selected from Fayoum organic farm, Tubhar village. $2918 \mathrm{~N}$ and $30^{\circ} 24^{\circ} \mathrm{E}$. Three organic fields which were under organic farming system for 4, 6 and 10 years and three adjacent fields representing the conventional fields. In Sharkyia Governorate, two different locations were selected, SEKEM organic farm, Bilbeis City, 30 $09^{\circ} \mathrm{N}, 31^{\circ} 25^{`} \mathrm{E}$ and Salhyia private organic farm, Salhyia El Gededdah City, $30^{\circ} 38^{`} \mathrm{~N}, 31^{\circ} 56^{`} \mathrm{E}$. Two organic fields which were under organic farming for 20 and 30 years as well as two adjacent conventional fields were sampled from SEKEM organic farm, and three organic fields which were under organic farming for 8,10 and 12 years and three adjacent conventional fields were sampled from Salhyia farm.

Soils were sampled first at 3/2012 and second at 3/2013 except those of Fayoum location which were sampled once, at 8/2012. Five soil sample replicates were taken per field, each replicate was a composite sample of three soil samples taken at random using an auger to a depth of $30 \mathrm{~cm}$. Soil samples were air dried and ground using a wooden hammer and sieved through a $2 \mathrm{~mm}$ mesh screen prior to the following chemical analyses:

Egypt. J. Soil Sci. 55, No. 2 (2015) 
Organic carbon was measured according to Walkley and Black, total nitrogen (T-N) by the Kjeldahl method (Page et al., 1982). Soil pH was measured in 1: 2.5 soil water suspensions, electrical conductivity (EC) was determined in 1:2.5 soil water ratio extract (Jackson, 1973). Available phosphorus was extracted with $0.50 \mathrm{M} \mathrm{NaHCO} 3$ solution according to Olsen et al. (Black. 1965) and determined according to Watanabe and Olsen (Page et al., 1982) procedure. Available potassium was extracted with ammonium acetate solution and determined photometrically (Jackson, 1973). Available micronutrients, (Fe, Mn, $\mathrm{Zn}$, and $\mathrm{Cu}$ ) were extracted according to Lindsay and Norvel (1978) method and determined using atomic absorption spectrophotometry (Unicam 767). Exchangeable cations and the cation exchange capacity of soil (CEC) were determined using an ammonium acetate method (Page et al., 1982).

\section{Statistical analysis}

Data were analyzed using a completely randomized design using Costat (Costat Statistical Software, 2003) and analysis of variance was used to determine significant differences among sampling time, period of organic certification, and farming system after transformation to normalize data and equalize variance as required. Significance level was set at $(\mathrm{P}<0.05)$. Comparison between means was made with the Duncan's multiple range (DMR) test. When treatment $\mathrm{x}$ year interactions was not significant, data were combined across years. Statistical analysis was made for each location separately.

\section{Results and Discussion}

\section{Soil organic carbon, $S O C$}

Soil organic carbon SOC has a beneficial impact on soil quality, enhancing soil structure and fertility, increasing water infiltration and storage (Magdolf, 2004).Analysis of variance indicated that SOC was significantly affected by farming system as well as the period of organic farming practice in the three studied locations. In Fayoum location (Fig. 1), the SOC content increased significantly (Table 1) from 10.89, 12.00 and $13.40 \mathrm{~g} / \mathrm{kg}$ in conventionally managed soils to $11.77,12.99$ and $15.69 \mathrm{~g} / \mathrm{kg}$ in soils that organically managed for 4, 6 and 8 years which represented 8.0, 8.2 and 18.9\% increases, respectively. In SEKEM samples, the corresponding increases were from 7.69 and $11.85 \mathrm{~g} / \mathrm{kg}$ in conventionally managed soils to 10.93 and $13.87 \mathrm{~g} / \mathrm{kg} \%$ increases in organically managed soils for 10, 20 and 30 years which represent 42.13 and $17.05 \%$ increases, respectively. In Salhyia samples, the SOC content followed the same trend as that of Fayoum and SEKEM samples, being higher in organically than conventionally managed soils by $14.4,13.6$, and $29.8 \%$ after 8,10 , and 12 years of organic farming management, respectively. A higher concentration of SOC is often considered to be an inevitable result of conversion to organic farming system (Stockdale et al., 2001). These results are in agreement with those reported by many authors who found a higher concentration of SOC in organically managed soils (Mader et al., 2002 and Pulleman et al., 2003). In 
Egypt, Omar et al. (2010) reported a comparable results, they found that total organic matter had increased in organically managed soils with the increase in organic farming period.

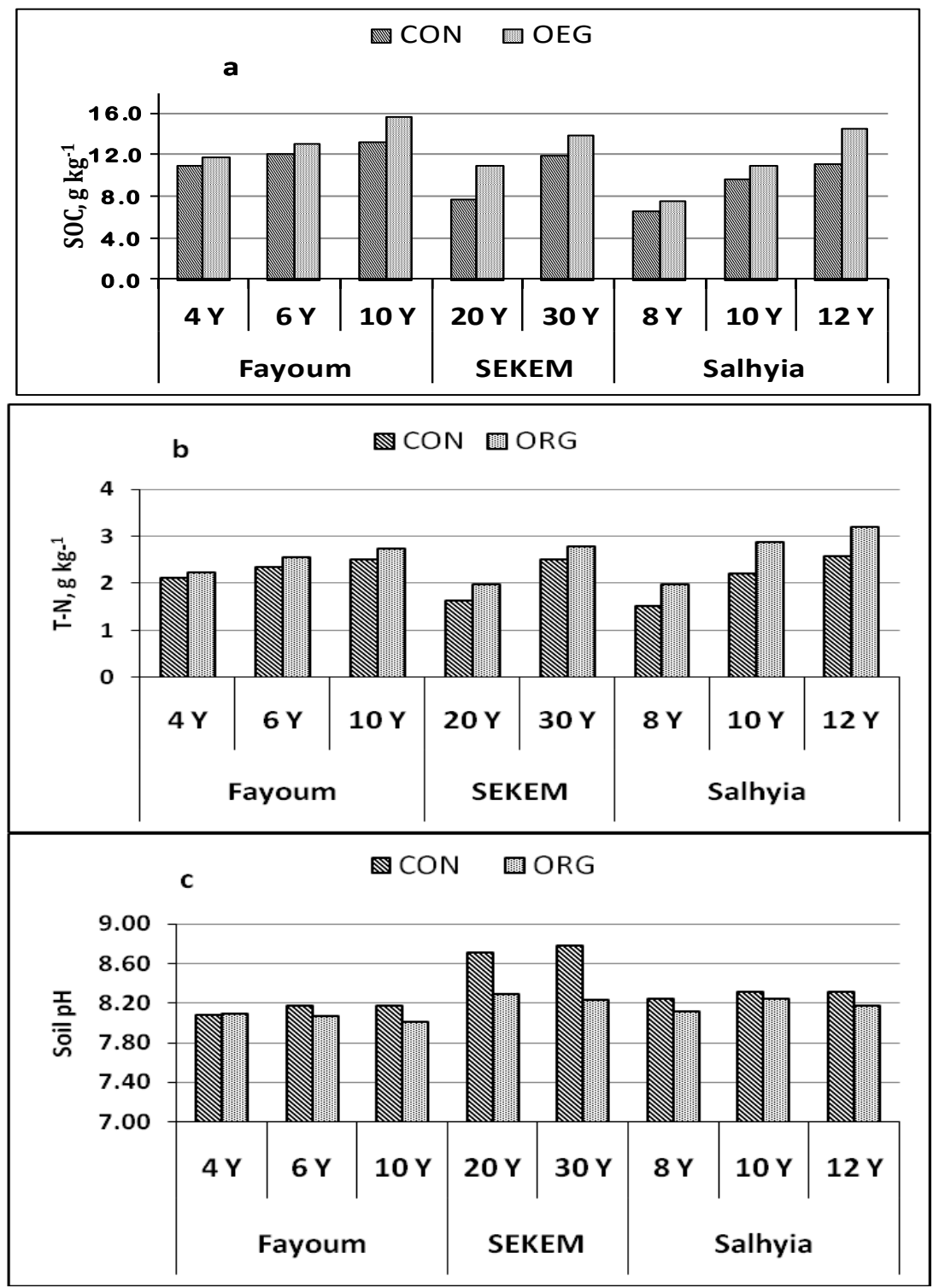

Fig. 1. Soil organic carbon (a), Total-N (b) and $\mathrm{pH}(\mathrm{c})$ as affected by farming system (CON \& ORG) and period of organic farming at the three locations (Fayoum, SEKEM \& Salhyia). 
TABLE 1. Analysis of variance for some soil properties as affected by season, period of organic farming (P), and farming system in different soil locations.

\begin{tabular}{|c|c|c|c|c|c|c|c|c|c|c|c|}
\hline Location & Source & $d f$ & SOC & $\mathbf{T}-\mathbf{N}$ & pH & EC & CEC & $\begin{array}{l}\text { Ex- } \\
\text { Ca }\end{array}$ & $\begin{array}{l}\text { Ex- } \\
\text { Mg }\end{array}$ & $\begin{array}{l}\text { Ex- } \\
\text { Na }\end{array}$ & Ex-K \\
\hline \multirow[t]{4}{*}{ Fayom } & Period, P & 2 & $* * *$ & $* * *$ & $* * *$ & $* * *$ & NS & $* *$ & $* * *$ & NS & NS \\
\hline & $\begin{array}{l}\text { Farming, } \\
\mathrm{F}\end{array}$ & 1 & **** & $* * *$ & *** & NS & $* * *$ & $* * *$ & $* * *$ & NS & $*$ \\
\hline & $\mathrm{P} * \mathrm{~F}$ & 2 & $* * *$ & $* * *$ & $* * *$ & $* *$ & **** & $*$ & $* * *$ & $* *$ & $* *$ \\
\hline & $\mathrm{CV}, \%$ & & 2.93 & 4.25 & 0.19 & 34.81 & 0.45 & 0.54 & 7.95 & 13.76 & 8.27 \\
\hline \multirow[t]{8}{*}{ SEKEM } & Season, $\mathrm{S}$ & 1 & NS & NS & NS & NS & $* * *$ & $* * *$ & NS & NS & NS \\
\hline & Period, P & 1 & $* * *$ & $* * *$ & $* *$ & $* * *$ & $* * *$ & $* * *$ & $* * *$ & $* * *$ & $* * *$ \\
\hline & Farming, F & 1 & $* * *$ & $* * *$ & $* *$ & $* * *$ & $* * *$ & $* * *$ & $* * *$ & $* * *$ & $* * *$ \\
\hline & $\mathrm{S} * \mathrm{P}$ & 1 & NS & NS & $* * *$ & NS & NS & NS & NS & NS & NS \\
\hline & $\mathrm{S} * \mathrm{~F}$ & 1 & NS & NS & *** & NS & NS & NS & NS & NS & NS \\
\hline & $\mathrm{P} * \mathrm{~F}$ & 1 & NS & NS & NS & **** & $* * *$ & $* * *$ & $*$ & $* *$ & NS \\
\hline & $\mathrm{S} * \mathrm{P} * \mathrm{~F}$ & 1 & NS & NS & $* *$ & NS & NS & NS & NS & NS & NS \\
\hline & $\mathrm{CV}, \%$ & & 11.89 & 11.03 & 1.30 & 9.8 & 1.84 & 2.31 & 17.70 & 11.27 & 9.76 \\
\hline \multirow[t]{8}{*}{ Salhyia } & Season, $\mathrm{S}$ & 1 & NS & NS & NS & NS & **** & $* * *$ & $* * *$ & * & NS \\
\hline & Period, $\mathrm{P}$ & 2 & $* * *$ & $* * *$ & $* * *$ & **** & $* * *$ & $* * *$ & $* * *$ & *** & $* * *$ \\
\hline & Farming, $\mathrm{F}$ & 1 & $* * *$ & $* * *$ & **** & $* * *$ & $* *$ & $* * *$ & $* * *$ & $* * *$ & $* * *$ \\
\hline & $\mathrm{S} * \mathrm{P}$ & 2 & NS & NS & NS & NS & $* *$ & NS & $* * *$ & NS & NS \\
\hline & $\mathrm{S} * \mathrm{~F}$ & 1 & NS & NS & NS & NS & NS & NS & $* * *$ & NS & NS \\
\hline & $\mathrm{P} * \mathrm{~F}$ & 2 & $* *$ & NS & $* *$ & $* * *$ & $\mathrm{NS}$ & NS & $* * *$ & $* *$ & $* *$ \\
\hline & $\mathrm{S} * \mathrm{P} * \mathrm{~F}$ & 2 & NS & NS & NS & NS & NS & $*$ & $* * *$ & NS & NS \\
\hline & $\mathrm{CV}, \%$ & & 10.87 & 10.89 & 2.10 & 15.67 & 2.88 & 2.40 & 10.17 & 10.99 & 13.41 \\
\hline
\end{tabular}
significant.

Analysis of variance summary (Table 1) indicated that soil total nitrogen (TN) followed almost the same trend as that of SOC, significantly affected by farming system and the period of organic farming practice and being higher in organically managed soils than in conventionally managed ones. The similar pattern observed between SOC and T-N is to be expected (Fig. 1), since the total nitrogen content of a soil is primarily a component of the soil`s organic matter content.

The percent increases in T-N concentration in Fayoum organically managed soils over conventionally managed ones were $5.7,9.4$ and $9.2 \%$ due to 4,6 , and 10 years of organic farming, respectively. The corresponding percentages for SEKEM samples were 22.10 and $11.16 \%$ due to 20 and 30 years of organic farming, respectively. While the percent increases for Salhyia were 29.60, 29.28 , and $23.64 \%$ due to 8,10 , and 12 years of organic farming, respectively. The higher levels of T-N are also observed in all of the organic soil with various plants by Wang et al. (2012). To some extent, higher $\mathrm{C}$ and $\mathrm{N}$ in organic farming system suggest that soil quality in organic farms has been improved (Wang et al., 2012). 


\section{Soil $p H$}

Soil $\mathrm{pH}$ was significantly (Table 1) affected by farming system as well as period of organic farming. All the soils of both conventional and organic fields were alkaline in reaction (Fig. 1). The $\mathrm{pH}$ values ranged from 8.01 to 8.24 in the organic fields and from 8.08 to 8.78 in the conventional fields. Organically managed soils exhibited a slight but significant decline in $\mathrm{pH}$ values compared with conventionally managed counterparts. The overall means of soil $\mathrm{pH}$ indicated that the $\mathrm{pH}$ values decreased from $8.15,8.29$ and 8.61 to $8.06,8.18$ and 8.23 in Fayoum, SEKEM and Salhyia samples, respectively. The decrease in soil $\mathrm{pH}$ in organically managed soils might be due to the formation of organic acids during decomposition and mineralization of organic manure and compost. Omar (2010) found that compost addition decreased soil pH of Fayoum and SEKEM samples with time in the batch and column experiments.

\section{Soil salinity, EC}

Analysis of variance (Table 1) showed that soil EC was significantly affected by farming system as well as period of organic farming. In general, EC value in each organically managed field was significantly less than its value in the conventionally managed counterpart, except one field in Fayoum samples. In Fayoum samples, the EC values ranged from 0.67 to $1.30 \mathrm{dS} / \mathrm{m}$ in the organic fields and from 0.77 to $2.08 \mathrm{dS} / \mathrm{m}$ in the conventional fields. The corresponding ranges for Salhyia location were from 0.41 to $0.84 \mathrm{dS} / \mathrm{m}$ and from 0.67 to 1.07 $\mathrm{dS} / \mathrm{m}$, respectively. In SEKM location, EC values followed the same trend, being significantly higher in conventionally managed soils than in organically managed ones. An exceptionally higher EC values were recorded in the 30 years of organic farming field and its conventional counterpart in SEKM due to the high salinity of the applied irrigation water in these fields.

The increase of the EC in the conventionally managed soils could be due to the higher input of salts in the form of chemical fertilizers and/or pesticides (Gasparatos et al., 2011). The relatively low EC levels in the organically managed soils indicate that the use of composts has not resulted in increased salinity (Clark et al., 1998). The results of the present study are in agreement with those of Stark (2005), Rahman et al. (2011) and Gasparatos et al. (2011).

\section{Cation exchange capacity (CEC) and exchangeable cations}

Cation exchange capacity (CEC) was significantly affected by organic farming system and the period of its management (Table 1). Organically managed soils had higher CEC values than their conventionally managed counterparts, However, the differences in CEC values between organic and conventional farming systems did not reach the significant level (at 0.05 significant level) until 6 years of organic farming (Table 1). On the other hand, there are significant increases between organic and conventional systems at higher periods of organic farming (8-30 years). The higher CEC in organic soil samples could be attributed to its greater organic C. Huang et al. (2002) found that cation exchange capacity is highly related to the amount of organic matter.

Egypt. J. Soil Sci. 55, No. 2 (2015) 
Exchangeable $\mathrm{Ca}$ almost followed the same trend as that of CEC (Fig. 2). This is not surprising since EX-Ca is the dominant cation on the exchange complex of the studied soils. On the other hand, exchangeable magnesium, EX$\mathrm{Mg}$, did not follow a consistent trend among the three locations, being significantly higher in organically managed soils in Fayoum and Salhyia locations, while the reverse trend was found in SEKEM location.
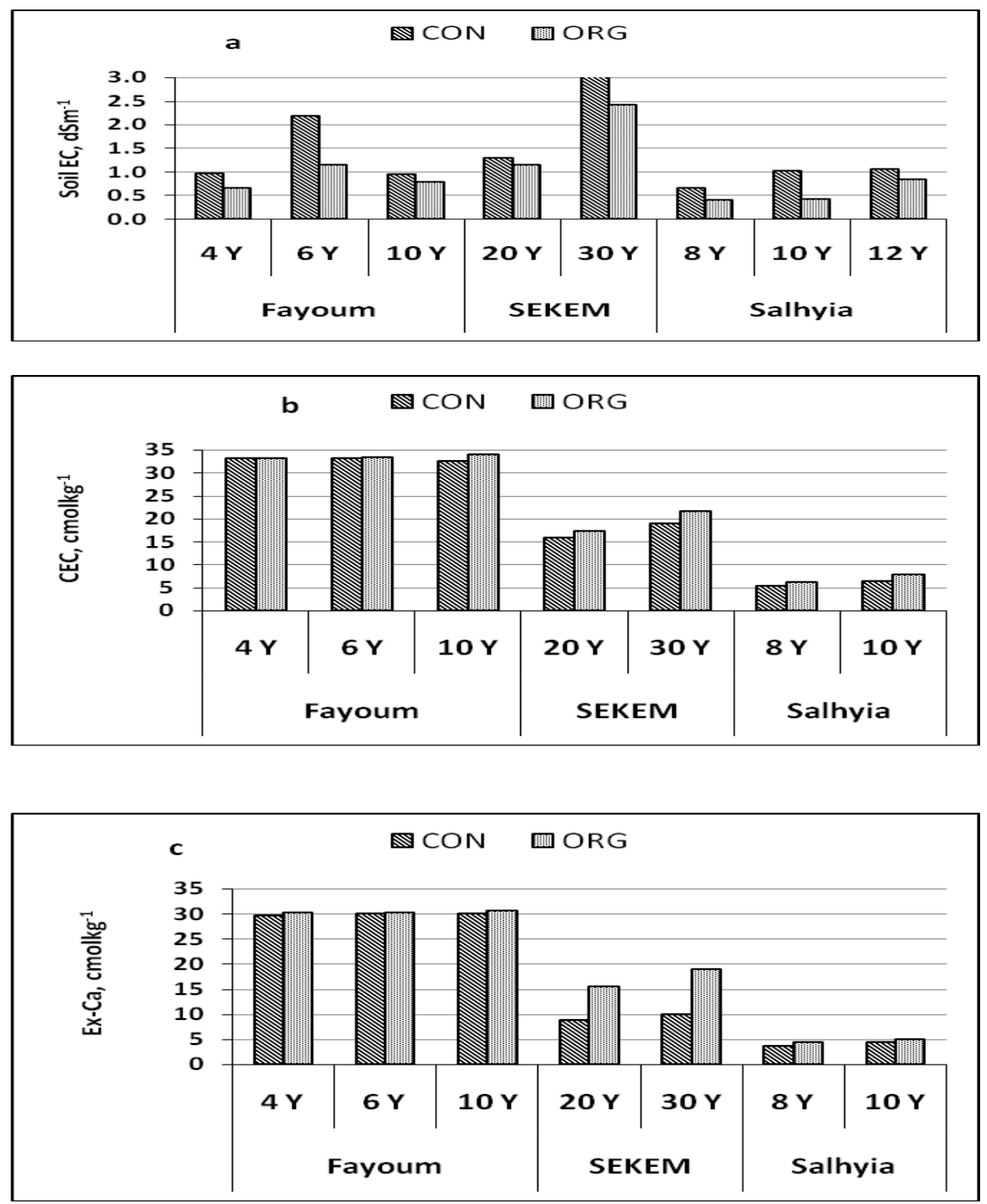

Fig. 2. Soil EC(a), CEC(b) and exchangeable-Ca(c) as affected by farming system (CON \& ORG) and period of organic farming at the three locations (Fayoum, SEKEM \& Salhyia). 
Exchangeable sodium (Ex-Na) was significantly lower in organically than conventionally managed soils in all locations, except the 4 year organically managed soil in Fayoum location, which showed a reverse trend (Fig. 3). On the other hand, conventionally managed soils had higher Ex-K than their organically managed counterparts which referred to inorganic addition of $\mathrm{K}$ fertilizers.
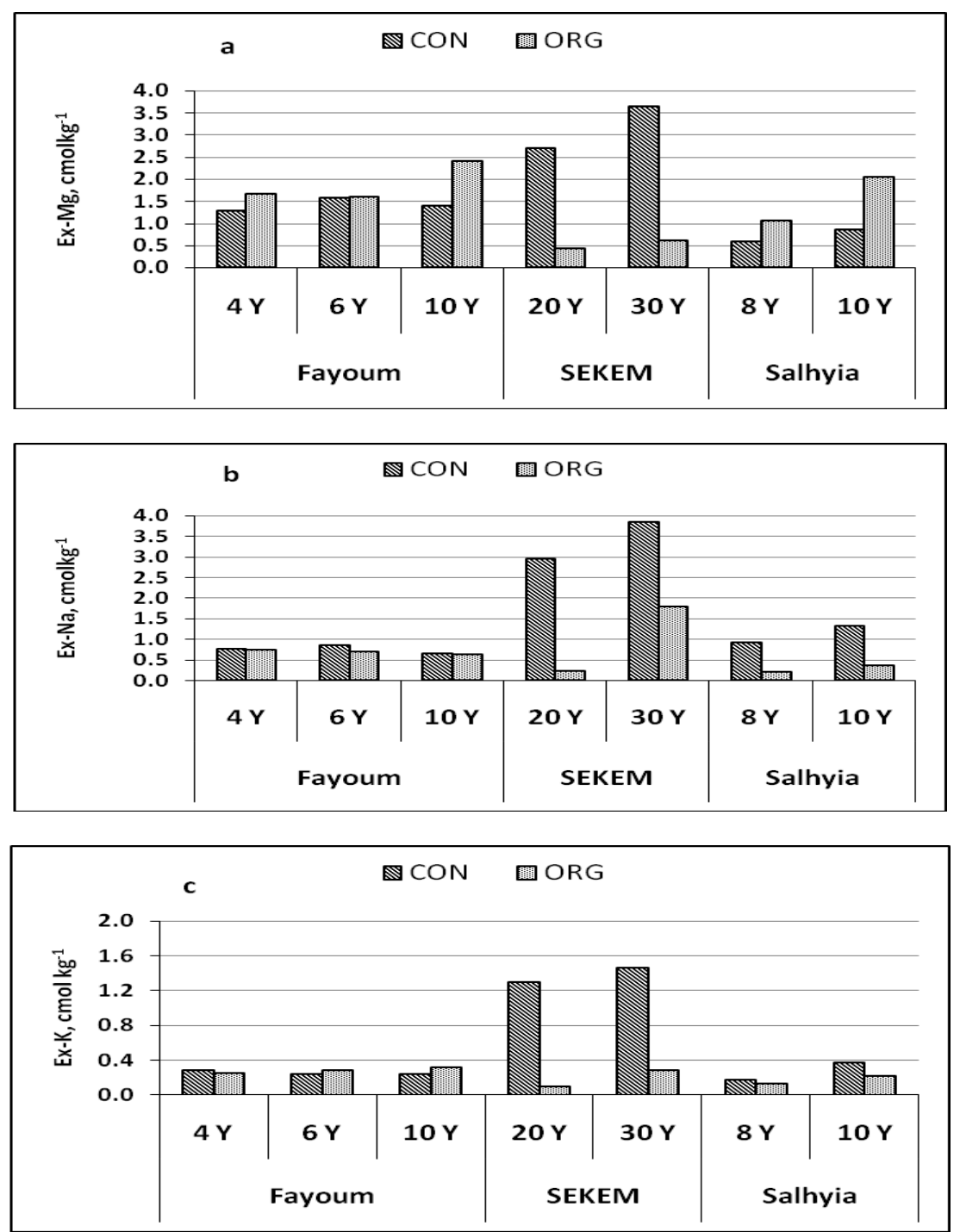

Fig. 3. Exchangeable-Mg(a), $\mathrm{Na}(\mathrm{b})$ and $\mathrm{K}$ (c) as affected by farming system (CON $\&$ ORG) and period of organic farming at the three locations (Fayoum, SEKEM \& Salhyia).

Egypt. J. Soil Sci. 55, No. 2 (2015) 
Availability of macronutrients ( $N, P$ and $K$ )

Organically managed soils contained higher levels of available $\mathrm{N}$ than the conventionally managed ones (Fig. 4). In Fayoum location, the concentration of available $\mathrm{N}$ increased by about 11.0, 4.0, and $37.0 \%$ in soils that managed organically as compared to conventional ones for 4,6 and 10 years, respectively. The corresponding increases in SEKEM location were 45.0 and $12.0 \%$ in soils managed organically for 20 and 30 years, respectively. While the corresponding increases in Salhyia location was 11.0, 26.0, and $37.0 \%$ in soil that organically managed for 8,10 and 12 years, respectively. The increase in available $\mathrm{N}$ in organically managed soils over conventionally managed ones could be due to the higher biological activity which accelerates the mineralize organically bound $\mathrm{N}$ to inorganic form (Bellakki and Badanur, 1997). These results are in agreement with those of Lehocka et al. (2008), Bhogal et al. (2008), Melero et al. (2006) and Ge et al. (2011).
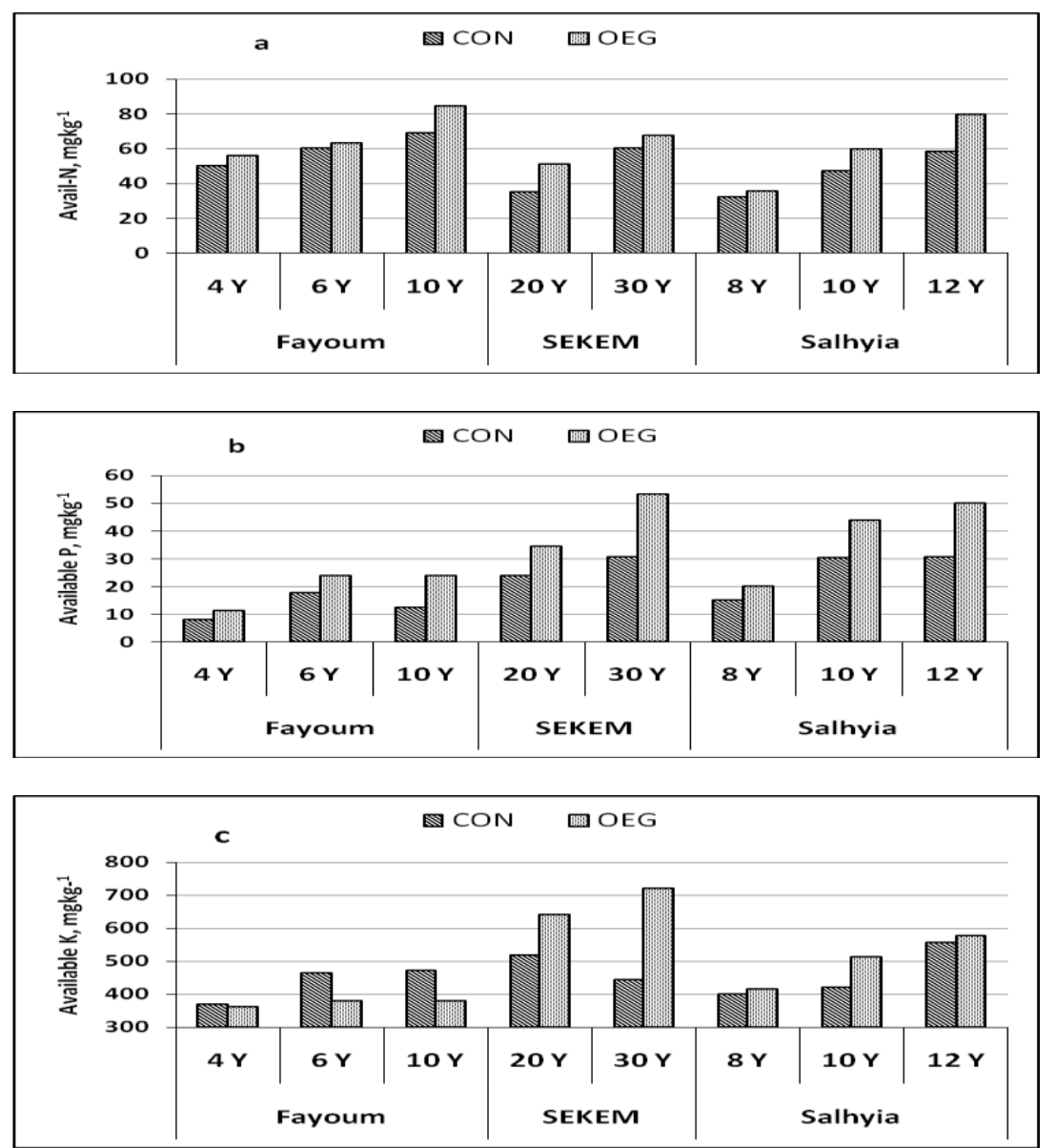

Fig. 4. Available-N (a ), P (b) and $K$ (c) as affected by farming system (CON \& ORG) and period of organic farming at the three locations (Fayoum, SEKEM \& Salhyia).

Egypt. J. Soil Sci. 55, No. 2 (2015) 
Statistical analysis (Table 2) revealed that available $\mathrm{P}$ was significantly increased progressively with increasing the period of organic farming within each location. Organically managed soils had higher $\mathrm{P}$ content than conventionally managed soils. Available P concentration ranged from 8.1 to 17.8 with an average of $12.8 \mathrm{mg} / \mathrm{kg}$ in conventionally managed soils and from 11.3 to 24.0 with an average of $19.7 \mathrm{mg} / \mathrm{kg}$ in organically managed soils in Fayoum. In Salhyia location, P concentration ranged from 15.0 to 30.7 with an average of $25.4 \mathrm{mg} / \mathrm{kg}$ in conventionally managed soils and from 20.0 to 50.2 with an average of $28.0 \mathrm{mg} / \mathrm{kg}$ in organically managed soils. In SEKEM location, $\mathrm{P}$ concentration ranged from 23.9 to 30.7 with an average of 27.3 $\mathrm{mg} / \mathrm{kg}$ in conventionally managed soils and from 34.4 to 53.4 with an average of $43.9 \mathrm{mg} / \mathrm{kg}$ in organically managed soils. The observed increase in available $\mathrm{P}$ levels appeared to be the direct result of inputs. The greatest amounts of $\mathrm{P}$ were applied to the organic systems as constituents of the applied composts and rock phosphate. These results are in agreement with those reported by Clark et al. (1998), Marinari et al. (2006), Herencia et al. (2008), and Gasparatos et al. (2011).

Available K concentration did not follow a consistent trend among the three locations (Fig. 4). In Fayoum location, K concentration was significantly higher in organic fields than conventional fields. However, in SEKEM and Salhyia locations, $\mathrm{K}$ concentration showed a reverse trend being significantly higher in conventional fields of SEKEM location and consistently higher in conventional fields of Salhyia location. The contrasted results regarding the behavior of available $\mathrm{K}$ in organic compared to conventional farming system were also reported by many authors. Clark et al. (1998), Edmeades (2003), Herencia et al. (2008) and Chhotaray et al. (2010) found that organically managed soils contained more available $\mathrm{K}$ than conventionally ones. On the other hand, Nguyen et al. (1995), Gosling et al. (2006), Abu-Zahra \& Thboub (2008), and Gasparatos et al. (2011) found that organically managed soils contained less available $\mathrm{K}$ than conventionally ones and claimed that organic farming is exploiting reserves of $\mathrm{K}$ that built up by fertilizer addition prior to organic management. In some organic farms the use of the powder of the K-bearing minerals (feldspar - biotite etc.) may increase the concentration of the availableK (Mikkelsen, 2008).

Availability of micronutrients ( $\mathrm{Fe}, \mathrm{Mn}, \mathrm{Cu}$ and $\mathrm{Zn}$ )

Available iron was significantly (Table 2) affected by organic farming system and period of organic farming in Fayoum and SEKEM locations. While in Salhyia location, differences in available- Fe between conventional and organic farming systems did not reach the significant level. However, in all locations, the organically managed soils contained higher available $\mathrm{Fe}$ and $\mathrm{Mn}$ than the conventionally ones (Table 2). In contrast, the available $\mathrm{Cu}$ and $\mathrm{Zn}$ were notably lower in organically managed soils than in conventionally managed ones (Fig. 5).

Egypt. J. Soil Sci. 55, No. 2 (2015) 
CHEMICAL AND FERTILITY INDICATORS OF SOIL QUALITY ...

TABLE 2. Analysis of variance summary for some available macro- and micronutrients as affected by season, period of organic farming (P) and farming system in different soil locations.

\begin{tabular}{|c|c|c|c|c|c|c|c|c|c|}
\hline Location & Source & $d f$ & $\mathbf{N}$ & $\mathbf{P}$ & $\mathbf{K}$ & $\mathrm{Fe}$ & Mn & $\mathbf{C u}$ & $\mathbf{Z n}$ \\
\hline \multirow{4}{*}{ Fayom } & Period, P & 2 & $* * *$ & $* * *$ & $* *$ & $*$ & NS & NS & $* *$ \\
\hline & Farming, F & 1 & $* * *$ & $* * *$ & $* * *$ & $*$ & $*$ & NS & NS \\
\hline & $\mathrm{P}^{*} \mathrm{~F}$ & 2 & $* * *$ & $* * *$ & NS & NS & NS & NS & NS \\
\hline & $\mathrm{CV}, \%$ & & 8.84 & 4.54 & 10.21 & 13.92 & 9.70 & 16.28 & 32.10 \\
\hline \multirow{8}{*}{ SEKEM } & Season, S & 1 & NS & $* * *$ & NS & NS & $* *$ & $* * *$ & NS \\
\hline & Period, $\mathrm{P}$ & 1 & $* * *$ & $* * *$ & NS & $* * *$ & NS & $* * *$ & $* * *$ \\
\hline & Farming, F & 1 & $* * *$ & $* * *$ & $* *$ & $* * *$ & $* * *$ & NS & $* * *$ \\
\hline & $\mathrm{S} * \mathrm{P}$ & 1 & NS & $* * *$ & NS & NS & NS & NS & NS \\
\hline & $\mathrm{S} * \mathrm{~F}$ & 1 & NS & $* * *$ & NS & NS & NS & NS & NS \\
\hline & $\mathrm{P} * \mathrm{~F}$ & 1 & $*$ & $* * *$ & NS & $*$ & NS & NS & $* * *$ \\
\hline & $\mathrm{S} * \mathrm{P} * \mathrm{~F}$ & 1 & NS & NS & NS & NS & NS & NS & NS \\
\hline & $\mathrm{CV}, \%$ & & 11.56 & 4.97 & 22.12 & 8.84 & 19.30 & 12.11 & 8.01 \\
\hline \multirow{8}{*}{ Salhyia } & Season, S & 1 & NS & $* * *$ & NS & NS & NS & NS & NS \\
\hline & Period, P & 2 & $* * *$ & $* * *$ & $* * *$ & NS & $* * *$ & NS & $* * *$ \\
\hline & Farming, $\mathrm{F}$ & 1 & $* * *$ & $* * *$ & $* *$ & NS & NS & NS & NS \\
\hline & $\mathrm{S} * \mathrm{P}$ & 2 & $* * *$ & NS & NS & NS & NS & NS & NS \\
\hline & $\mathrm{S} * \mathrm{~F}$ & 1 & NS & Ns & NS & NS & NS & NS & NS \\
\hline & $\mathrm{P} * \mathrm{~F}$ & 2 & $* *$ & $* * *$ & NS & NS & $* *$ & NS & NS \\
\hline & $\mathrm{S} * \mathrm{P} * \mathrm{~F}$ & 2 & $* *$ & NS & NS & NS & NS & NS & NS \\
\hline & $\mathrm{CV}, \%$ & & 15.38 & 9.93 & 10.99 & 22.51 & 25.17 & 55.90 & 13.84 \\
\hline
\end{tabular}

*,**,*** Significant at the $0.05,0.01$, and 0.001 probability levels, respectively, NS $=$ not significant.

The above mentioned results regarding available micronutrients are in agreement with those reported by several authors. Herencia et al. (2008) found that organically managed soils had more $\mathrm{Fe}$ and $\mathrm{Mn}$ than the conventionally ones, they reported that the slightly higher levels of these micronutrients could be due to the formation of soluble organic complexes with the organic materials. The lower concentration of $\mathrm{Cu}$ and $\mathrm{Zn}$ in organically managed soils compared to conventionally managed soils could be due to the application of agrochemicals, such as pesticides (cupper containing fungicides) and synthetic fertilizers (containing both $\mathrm{Cu}$ and $\mathrm{Zn}$ ), in the conventional farming system (Gasparatos et al., 2011). 

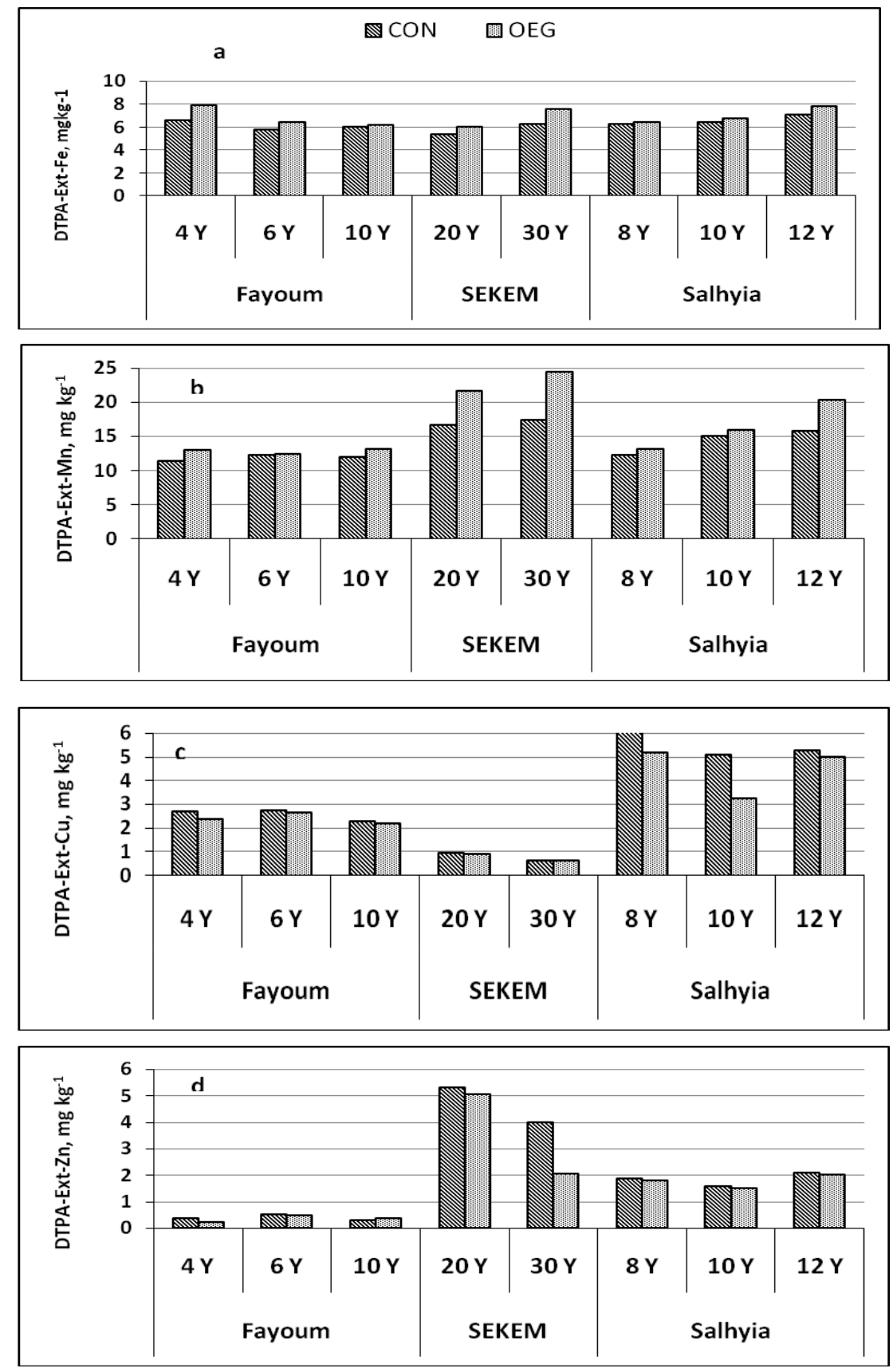

Fig. 5. DTPA-extractable micronutrients; $\mathrm{Fe}(\mathrm{a}), \mathrm{Mn}(\mathrm{b}), \mathrm{Cu}$ (c) and $\mathrm{Zn}(\mathrm{d})$ as affected by farming system (CON \& ORG) and period of organic farming at the three locations (Fayoum, SEKEM \& Salhyia).

Egypt. J. Soil Sci. 55, No. 2 (2015) 


\section{Refrences}

Abu-Zahra, T.R. and Tahboub, A.B. (2008) Effect of organic matter sources on chemical properies of the soil and yield of strawberry under organic farming conditions. World Apll. Sci. J., 5, 383-388.

Araujo, A.S., Leite, L.F., Santos, V. B. and Carneiro, R. F. (2009) Soil microbial activity in conventional and organic agricultural systems. Sustanability, 1, 268- 276.

Babu, M.V., Parma, M. R. and Anil, K. S. (2010) Enzymes activities in soils under central dry agro climate zone of Karnataka, India as influenced by soil depth, organic and conventional management systems. EJBS, 3, 50-53.

Bellakki, M.A. and Badanur, V.P. (1997) Long-term effect of integrated nutrient management on properties of vertisol under dryland agriculture. J. Indian Soc. Soil Sci., 45, 438-442.

Bhogal, A., Nicholson, F. A. and Chamber, B. (2008) Organic carbon additions effects on soil bio-physical and physic-chemical properties. Europ. J. Soil Sci., 60, 276-286.

Black, A., Evans, D.D., Ensminger, F.E., White, J. I., Clark, F.E. and Dinaver, R.C. (1965) Methods of Soil Analysis (Part I \& II) ser. Argon. No. 9 Am. Soc. Agron. , Madison, Wisconsin.

Chhotaray, D., Mohapatra, P.K. and Mishra, C.S.K. (2010) Macronutrient availability and microbial population dynamics of soils under organic and conventional farming of legume crop. The Bioscan: special issue, 3, 643-650.

Clark, M.S., Horwath, W.R., Shennan, C. and Kate Scow, M. (1998) Changes in soil chemical properties resulting from organic and low-input farming practices. Agron. J., 90, 662- 671 .

CoStat Statistical Software (2003) CoHort v. 6.2, Monterrey, CA.

Edmeades, D.C. (2003) The long-term effects of manures and fertilizers on soil productivity and quality: a review. Nutrient Cycling in Agroecosystems, 66, 165-180.

Gajda, A. and Martyniuk, A. (2005) Microbial biomass $\mathrm{C}$ and $\mathrm{N}$ and activity of enzymes in soil under winter wheat grown in different crop management systems. Polish J. Environ, 14, 159-163. (c.f. Araujo et al., 2009).

Gasparatos, D., Roussos, P.A., Christofilopoulou, E. and Haidouti, C. (2011) Comparative effects of organic and Conventional apple orchard management on soil chemical properties and plant mineral content under miditerranean climate conditions. J. Soil Sci. Plant Nutrit., 11,105-117.

Ge, T., Ni, S., Wu, J., Shen, J., Xiao, H., Tong, C., Huang, D., Hong, Y. and Iwaski, K. (2011) Chemical properties, microbial biomass, and activity differ between soils of organic and conventional horticultural systems under greenhouse and open field management: a case study. J. Soils Sediments, 11, 25-36. 
Gosling, P., Hodges, A., Goodlass, G. and Bending, G.D. (2006) Arbuscular mycorrhizal fungi and organic farming. Science, 296,1694-1697.

Hathaway-Jinkins, L. J., Sakrabani, R., Pearce, B., Whitmore, A. P. and Goodwin, R. J. (2011) A comparison of soil and water properties in organic and conventional systems in England. Soil Use and Management, 27,133-142.

Herencia, J. F., Ruiz, J.C., Melero, S., Garcia Galavis, P.A. and Maqueda, C. (2008) A short-term comparison of organic $v s$. conventional agriculture in a silty loam soil using two organic amendments. J. Agric. Sci., 146, 677- 687.

Huang, Y., Liu, S., Shen, Q. and Zong, L. (2002) Influence of environment factors on the decomposition of organic carbon in agriculture soils. Chin Appl Ecol., 13, 709714.

Jackson, M. L. (1973) Soil Chemical Analysis. Printice Hall of India Private Limited, New Delhi.

Lehocka, Z., Klimikova, M. and bielikova, M. (2008) Soil quality indicators in organic and conventional farming systems in Slovakia. $16^{\text {th }}$ IFOAM Organic World Congress, Modena, Italy.

Lindsay, W. L. and Norvell, W. A. (1978) Development of a DTPA soil test for zinc, iron, manganese, and copper. Soil Sci. Soc. Am. J., 42, 421- 428.

Liu, B., Tu, C., Hu, S., Gumpertez, M. and Ristaino, J.B. (2007) Effect of organic, sustainable, and conventional management strategies in grower fields on soil physical, chemical, and biological factors and the incidence of Southern blight. Appl. Soil Ecol., 37, 202-214.

Mader, P., FileBbach, A., Dubois, D., Gunst, L., Fried, P. and Niggli, U. (2002) Soil fertility and biodiversity in organic farming. Science, 96, 1674- 1696.

Marinari, S., Mancinelli, R. and Campiglia, E. (2006) Chemical and biological indicators of soil quality in organic and conventional farming systems in Central Italy. Ecolog. Indic., 6, 701-711.

Mazzoncini, M., Canali, S., Giovannetti, M., Castagnoli, M., Tittareli, F., Antichi, D., Rannelli, R., Cristani, C. and Barberi, P. (2010) Comparison of organic and conventional stockless arable systems: A multidisciplinary approach to soil quality evaluation. Appl. Soil Ecol., 44, 124-132.

Melero, S., Porras, J.C.R., Herencia, , J.F. and Madejon, E. (2006) Chemical and biochemical properties of a clay soil under conventional and organic management. Soil Till. Res. 90, 162-170.

Mikkelsen, R. (2008) Managing Potassium for Organic Crop Production. Better Crops/ 92 (2008, No. 2), 26-29.

Nguyen, M. L., Haynes, R. J. and Goh, K. M. (1995) Nutrient budgets and status in three pairs of conventional and alternative mixed cropping farms in Canterbury, New Zealand. Agric. Ecosyst. Environ. 52, 149-162.

Egypt. J. Soil Sci. 55, No. 2 (2015) 
Okur, N., Altindisli, A., Cengel, M., Gocmez, S. and Kayikcioglu, H. H. (2009) Microbial biomass and enzyme activity in vineyard soils under organic and conventional farming systems. Turk. J. Agric. For, 33, 413-423.

Omar, M. A. D. (2010) Forms and Distribution of Some Nutrients in Soils under Organic Farming Conditions. Ph.D. Thesis, Fac. of Agric., Cairo Univ., Egypt.

Page, A. L., Miller, R. H. and Keeney, D. R. (1982) Methods of Soil Analysis. Part 2: Chemical and Microbiological Properties. $2^{\text {nd }}$ ed., Am. Soc. of Agron., Madison, Wisconsin, USA.

Pulleman, M., Jongmans, A., Marinissen, J. and Bouma, J. (2003) Effects of organic versus conventional arable farming on soil structure and organic matter dynamics in a marine loam in the Netherlands. Soil Use and Management, 19, 157-165.

Rahman, M. H., Allister, W., McCuvran, A. G. and Saunders, S. J. (2011) Impact of management systems on soil properties and their relationships to kiwifruit quality. Comm. Soi Sci. Plant Anal., 24, 332-357.

Stark, C. (2005) Effects of Long- and Short-term Crop Management on Soil Microbial Properties and Nitrogen Dynamics. Ph.D. Thesis, Lincoln Univ., 277p. Available from: http://www.merfield.com/Christine-Stark-phd.

Stockdale, E.A., lampkin, N. H., Hovi, M., Keatinge, R., Lennartsson, E.K., Macdonald, D.W., Padels, S., Tattersall, F. H., Wolfe, M. S. and Watson, C. A. (2001) Agronomic and environmental implications of organic farming systems. $A d v$. Agron., 70, 261-325.

Wang, S., Li, Z. and Fan, G. (2012) Soil quality and microbes in organic and conventional farming systems. African J. Microbiology Res., 69, 5077-5085.

Watson, C. A., Stockdale, E. A. and Rees, R. M. (2008) Assessment and maintenance of soil fertility in temperate organic agriculture. CAB Reviews: Perspective in Agriculture, Veterinary Sci., Nutrition and Natural Resources, 3(219), 1-11.

Willer, H. and Klicher, L. (2012) The World of Organic Agriculture: Statistics and Emerging Trends 2012. IFOAM, Bonn, and FiBL, Frick.

(Received 15/10/2014 accepted $1 / 10 / 2015)$ 


\section{المعايير الكيميائية و والخصوبية لجودة التربة لأنظمة الزراعة العضوية و التقليدية تحت الظروف المصرية}

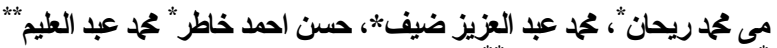

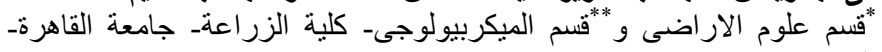

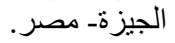

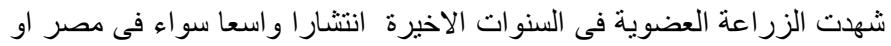

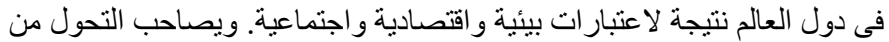

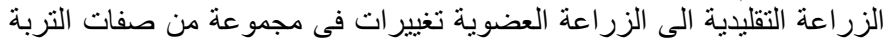

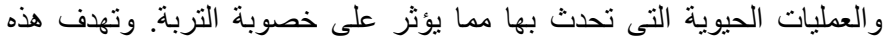

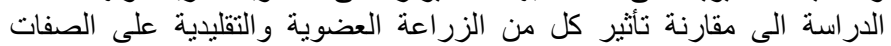
الكيميائية والخصوبية للتربة تحت الظئية الظروف الزئ المصرية. شملت الصفات الكيميائية

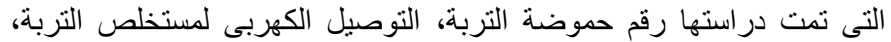

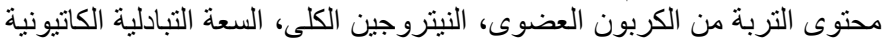

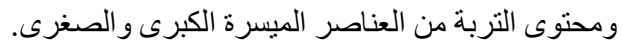

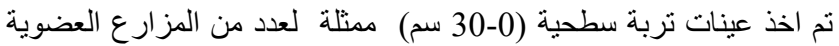

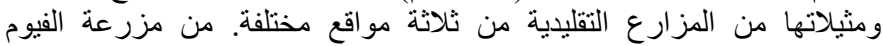

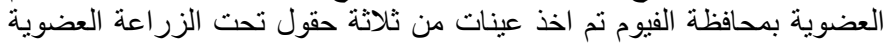

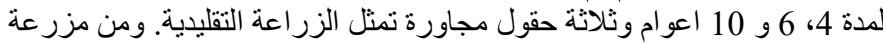

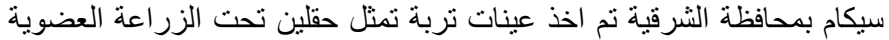

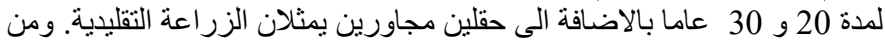

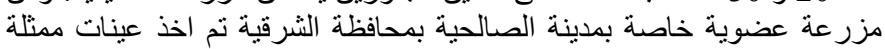
لثناثة حقول تحت الزر اعة العضوية لمدة 8 ، 10 و 12 عاما بالاضافة الى ثنلاثة حقول مجاورة تمثل الزر اعة الزراعة التقليدية.

وتثير النتائج المتحصل عليها الى ان الار اضى تحت نظام الزر اعة العضوية

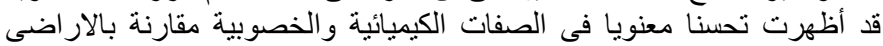

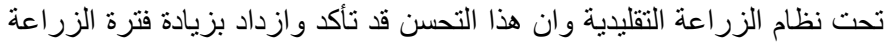
العضوية. 